Polloy, Planning, and Research

WORKING. PAPERS

Agriculture

Latin America and Caribbean

Country Department II

The World Bank

March 1989

WPS 163

\title{
How Infrastructure and Financial Institutions Affect Agricultural Output and Investment in India
}

\author{
Hans P. Binswanger, \\ Shahidur R. Khandker, \\ and \\ Mark R. Rosenzweig
}

Prices matter - but so do banks, markets, and infrastructure. 


\section{WORKING PAPERS}

Agriculture

How do the decisions of farmers, financial institutions, and govemment agencies interact and affect agricultural investment and output in a region - and to what extent are these "actors" influenced by a region's location and agroclimatic endowments (for example, rainfall or the soil's moisture-holding capacity).

This paper is an attempt to quantify the relationships of key factors, using district-level time-series data from India.

Agricultural opportunities in a district are seen as the joint outcome of the agroclimatic endowments of the district and new technology that becomes available to it. Better agroclimatic opportunities improve output (relation 1), but also increase the economic retum for a private farm investment - say, in a tractor (relation 2). Greater private profit in a well-endowed region induces farmers to press for more investment in infrastructure (relation 3). Financial institutions find it more profitable to locate where there is more demand for capital and more repayment capacity (relation 4) and where good infrastructure reduces their costs (relation 5). Private agricultural investment and use of input is more profitable the better the agricultural opportunities (relation 2), the better the infrastructure (relation 6), the cheaper the cost of financial services (relation 7), and the more favorable govemment's price and interest policies (relation 8). Exactly the same factors affect the output supply (relations 9, 10,11). Traditional approaches to production function estimate the direct impact of capital stocks (investment) and input use on output (relation 12), ignoring many of the factors discussed here.
After comparing data on these factors, the authors conclude that:

- Agroclimatic factors continue to govern the rate at which districts can take advantage of new agricultural opportunities, and govern public, bank, and private investment decisions.

- The availability of banks (credit) is more important than the real interest rate as a factor in aggregate crop output and farmers' demand for fertilizer. Rapid bank expansion in an area increased fertilizer demand by about 23 percent, rates of investment in pumps 41 percent, in milk animals 46 perceni, and in draft animals about 38 percent. Despite their impact on investment and fertilizer use, the impact of banks on output appears to be fairly small (nearly 3 percent).

- Unsurprisingly, commercial banks prefer to locate in well-watered areas where the risk of drought or flood is relatively low. Bank expansion is facilitated by government investments in roads and regulated markets, which improve farmers' liquidity and reduce banks' and farmers' transaction costs.

- In the 1970s, expansion of regulated markets contributed 4 percent to growth of agricultural output and 17 percent to demand for fertilizers. Expansion of electrification increased output 2 percent in a decade by increasing investment levels for pumps and fertilizer. A primary education added a large 8 percent to crop output over the decade, primarily by increasing fertilizer demand nearly 30 percent.

This paper is a product of the Agriculture Operations Division, Latin America and Caribbean Country Department II. Copies are available frec from the World Bank, 1818 H Street NW, Washington DC 20433. Please contact Josefina Arevalo, room 17-100, extension 30745

The PPR Working Paper Series disseminates the findings of work under way in the Bank's Policy, Planning, and Research Complex. An objective of the series is to get these findings out quickly, even if presentations are less than fully polished. The findings, interpretations, and conclusions in these papers do not necessarily represent official policy of the Bank. 
THE IMPACT OF INFRASTRUCTURE AND FINANCIAL INSTITUTIONS ON AGRICULTURAL OUTPUT AND INVESTMENT IN INDIA

by

Hans P. Binswanger, Shahidur R. Khandker, and Mark R. Rosenzweig

Table of Contents

I. Introduction.......................... 1

II. Analytical Eramework................... 3

III. Data and variables..................... 11

IV. Agroclimatic Endowments, Infrastructure, Population and Crop Output................ 17

v. Development of Commercial Banks............. 22

vI. Determinants of Private Investment............ 24

VII. Determinants of Fertilizer Demand and Aggregate Crop Output......................... 31

vIII. Discussion........................ 35

References.............................. 42 


\section{Introduction}

Government expenditure on physical infrastructure and human resource development influence the private production and Investment decisions in agriculture and thus are essential ingredients of increased agricultural productivity. Government Investments (both physical and human) can directly Increase agriculiural output by shifting the production frontler as in the case of Irrigation. This is what alght be called the direct effect of government infrastructure. Government Investment also increases the rate of return to private agricultural Investment and thereby leads to greater Investment and output. Moreover, by Increasing the viability and profitablitty of financial intermedlaries; infrastructure can facilitate the emergence and growth of financial institutions that increase access to working and investment capital or reduce the costs of borrowing for long-term Investment. Better credit fac1lit1es, by enabling the smoothing of consumption, may also increase the wlilingness of farmers to take risk.

1/ This paper would not have been feasible without the patient and persistent efforts of a large number of people who assembled, checked and processed the enormous data base required. The ICRISAT economics staff graciously provided thelr district data base for the semiarid tropics. Robert Evenson and Ann Judd in turn contrlbuted their North Indla district data base. James Barbleri assembled the data required to update these data bases to 1982, added additional staces, and collected the data on banking, on private capital stocks and investment. He was advised in this endeavor by Devendra B. Gupta who provided the liaison with the respective Indian authorlties who were graclous to release data which were st111 in manuscript form. Dr. D.R. Gadg11 opened the data base of NABARD and personally organized the Continued on next page 
Thus agricultural output and investinent respond to the separate actions undertaken by three economic actors-- farmers, government agencies and banks. All three actors respond positively to agricultural opportunities implied in the agroclimatic endowments of a rogion and in new technologies when it becomes avallable. The magnitude of the effects depends on how each of the actors responds to agricultuial opportunities and how farmers and banks respond to the government investment decisions. This paper seeks to quantify the inter-relationships among the investment decislons of government, financlal institutions and farmers and their effects on agricultural investment and output.

The central problem of estimating these relationships is that, once government agencies and banks are admitted as actors who respond to agricultural opportunities, one can no longer take the distribution of government infrastructure and banking institutions as exogenously given or randomly distributed. The impact of government infrastructure on Investment and output is likely to be more pronounced in a better endowed region than in a poor endowed region and governments will therefore invest more where opportunfties are greater. The resulting unobserved variable problem may be circumvented by elther a precise quantitative characterisation of the agroclimatic potential or by using the fixed effects țechnique of estimation. For analyzing growth in aggregate output

Continued from previous page assembly of the banking data. Apparao Katikineni organized the screening, and further computer processing of the many different and disparate data bases which had to be merged into a single data base. Kathy Graham did all of the cartographic measurements. We were also assisted by Sneylata Gupta and Dan Ghura. 
both Blnswanger, Yang, Bowers and Mundlak (BYBM, 1986) and Lau and Yotopoulos (1988) have implemented the appropriate fixed effects technique using time-series $x$ cross section data of countries. 2

The paper is structured in the following order. Section II outlines an analytical framework. Section III describes the data and discusses the variables. Section IV shows how various agroclimate variables affect government decision on where to build roads, markets and schools and where to provide electricity and canal irrigation. Section $V$ looks at the joint impact of agroclimatic endowments and infrastructure on the growth of financial intermediaries. We do this in a cross-section and time series framework using district level data from India. Section VI then considers the folnt determination of private agricultural investment as functions of agroclimatic endowments, technology change, infrastructure, financial intermediaries and of price and interest policy. In Section VII we estimate the impact of the same variables on fertilizer demand and aggregate crop output. The results are surmarized in the concluding part of the paper.

\section{iI. Analytical Framework}

In our framework (see Figure 1), agricultural opportunities in a district are the joint outcome of the agroclimatic endowments of the district and the new technology which becomes avallable to the district

2I Bapna, Binswanger and Quizon (BBQ, 1984) used random effects techniques to analyze output supply in time-series $x$ čross section daca of districts in India. 


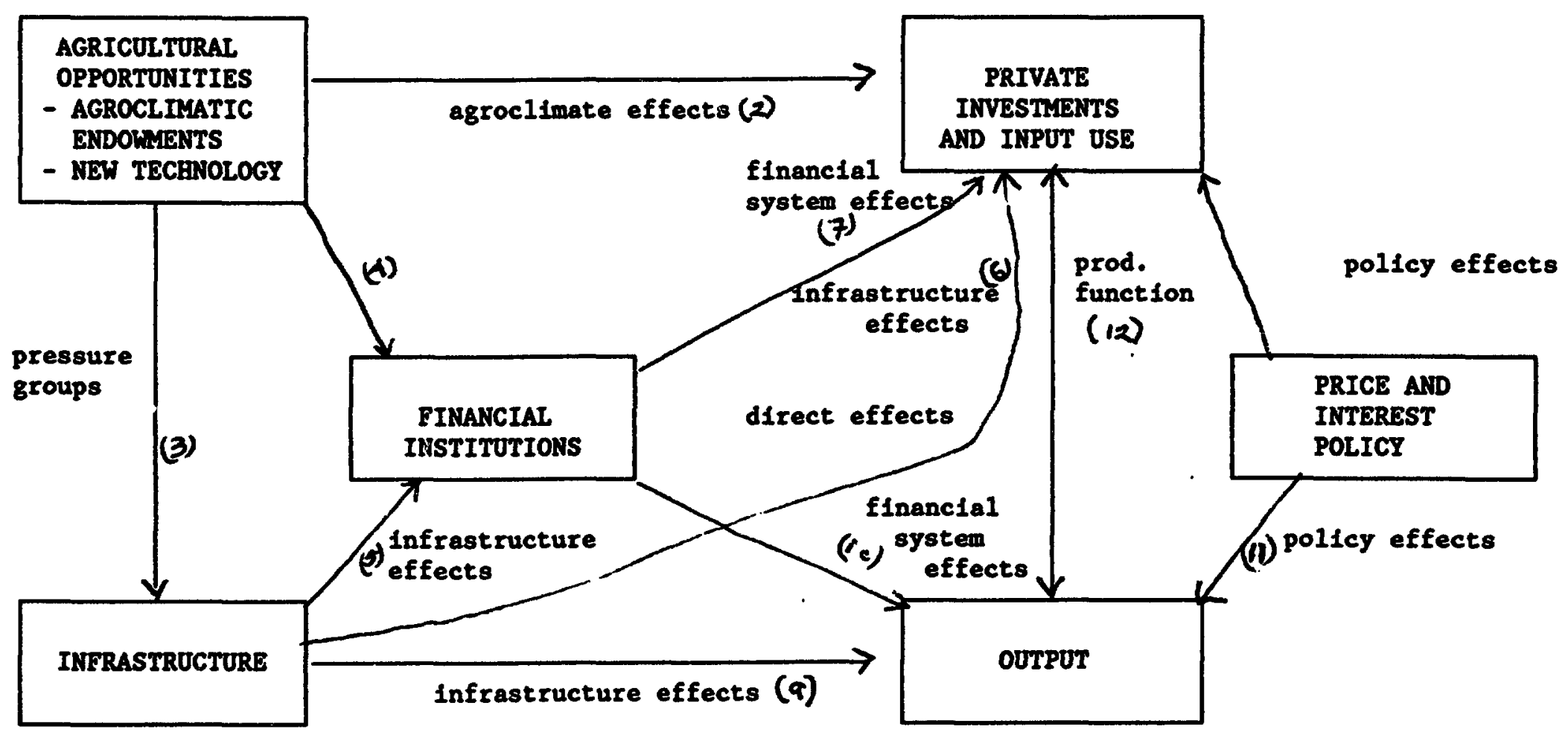

Figure 1: Major Relationships mong Agroclimate Bndownents, Financial Institutions, Government Infrestructure and Agricultural Investment and Output 
from industry and from forefgn, natlonal and state research systems. 3 T:ee same technology is potentially avallable to all districts, but the exten: to which it is actually applicable to a given district depends on its agroclimatic endowments. For examplo high yielding varleties of wheat are not relevant for districts with high inter cemperatures or districts with excessive amounts of rainfall and flonding problems. Thus the s1ze and the growth of the set of agricultural opportunities varies across a district according tu their agroclimatic characteristics.

Better agroclimatic opportunities such as better ralnfall, a higher moisture holding capacity of the soll and a better irrigation potential directly affect agricultural output (relation 1). But better opportunities also Increase the economic return to private farm investments such as tractors; draft animals or pumpsets (relation 2). The greater private profitability of agriculture in well endowed regions induces farmers to press government for increased investment in the supportive infrastructure (relation 3). Financlal institutions find it more profitable to locate in environments where a good agroclimate and rapid technical change leads to a substantial demand for agricultural investment and-working capital and a high repayment capacity (relation 4) and where good Infrastructure reduces their cost of intermediation (relation 5). Private agricultural investment and input use is more profitable the better the agricultural opportunities (relation 2), the better the government

3/ Although technology investments are themselves government decision variables, for the purpose of this paper technology is treated as exogenous to the decisionmaking of specific government agencles, banks and farmers when they make investment, location and input decisions. 
Infrastructure (relation 6), the cheaper the cost of financial services (relition 7) and the more favorable price and interest policies are which are pursued by the government (relation 8 ). Exactly the same factors affect the output supply. (relation 9, 10, 11). This means that agricultural opportunities must be translated into public and private Investment ifforts in order to affect agricultural output (For a discussion see BYBM, 1986 and Mundlak, 1985).

The craditional production function approach has attempted to estimate the direct impact of capital stocks (Investment) and input use on output, (relation 12), ignoring much of the factors discussed here and all the simultaneity problems (see for example Hayami and Ruttan, 1986).4

\section{Estimation Equations and Econometric Specifications}

Let $R_{r j t}$ be the level of the $x$-th infrastructure variable (say. roads) in district $j$ at time $t$. As agroclimate variables are strictly exogenous, the dependence of the infrastructure variables on a set of measured agroclimate variables and location factors $\sigma_{j}$ can be estimated simply in a cross section regression

$$
\text { (1) } \quad R_{r j t}=R_{r j t}\left(\sigma_{j}, \mu_{j}, \epsilon_{j t}\right)
$$

I/ A profit-oriented producer will take input and output decisions jointly. In order to deal with this simultanelty, the correct way to estimate the production function (12) is to use the predicted instead of actual levels of capital stocks and other inputs. However, as clearly apparent from figure 1 , we do not have any instruments which affect only the inpurs but not the output. - Therefore the production function cannot be estimated econometrically. 
where $\mu_{j}$ is the effect of unmeasured agroclimatic and location factors, and $E_{j t}$ is a time-specific error term. 5

Financial institutions in turn are essumed to locate in districts with good agroclimate and Infrastructure, 1.e.

\section{(2) $B_{j t}=B_{j t}\left(R_{j t}, \sigma j, \mu j, T_{j t}, \epsilon_{j t}\right)$}

where $B_{j t}$ stands for the number of banks operating in the district at time $t, T_{j t}$ is a region-and time-specific technology index, and $\epsilon_{j t}$ is an error term specific to the banking equation.

The simultaneity between banks, $B_{j t}$, and infrastructure, $R_{\mathbf{j t}}$, arising from their joint dependence on unobserved agroclimatic variables, $\mu_{f}$, can be overcome if an additive modiel is chosen such as

$$
\text { (3) } B_{j t}=a_{0}+a_{1} R_{j t}+a_{2} \sigma_{j}+a_{3} \mu_{j}+T_{j t}+\epsilon_{j t}
$$

For the mean overtime in district $j$ this relationship reads

$$
\text { (4) } \bar{B}_{j \cdot}=a_{0}+a_{1} \bar{R}_{j}+a_{2} \sigma_{j}+a_{3} \mu_{j}+\bar{T}_{j} \cdot+\bar{\epsilon}_{j} \cdot
$$

Taking the difference of these equations, 1.e. by transforming the varlables to differences from their means, leads to the following estimation equation in terms of difference from the means

$$
\text { (5) }\left(B_{j t}-\bar{B}_{j \cdot}\right)=a_{1}\left(R_{j t}-\bar{R}_{j}\right)+\left(T_{j t}-\bar{T}_{j}\right)+\left(\epsilon_{j t}-\epsilon_{j \cdot}\right)
$$

I/ Similar ultimate reduced forms can be established for all other endogenous variables in the system, the banks, private investment and output. However, the reduced forms for output, for example, is not very informative as it includes both the ditect or technical impact of the agroclimate on output (relation (1)) as well as all the indirect effects via its impact on infrastructure, banks and private investment. 
As $\epsilon_{j t}$ is a randomly distributed error term which is uncorrelased with $\sigma_{j}$ and $R_{j t}$, relationship (5) can be estimated by the Ordinary Least Squares technique.

The disadvantages of using this flxed effects model is that the direct Impact of the agroclimate (1.e. relation (4)) cannot be estimated. 6 These direct effects could only be estimated (In this and all subsequent equations) if the Infrastructure varlables were randomly distributed acre's the districts, 1.e. were not dependent on the unobserved agroçlimatic variables $M_{j}$. This could happen if the measurement of the obsexved agroclimatic variables $\sigma_{\mathfrak{j}}$ were so good that no unobserved effects were left over to significantly affect the Infrastructura investments. In that case a random effects model would be approprfate. We w11l use Hausman-Wu . specification tests to determine whether to use the fixed effects or rancom effects model and present results accordingly.

Private agricultural investment in capital item $k$ (say draft animals or tractors), depends on the agroclimate, the infrastructure and the banks. In addition it depends on policy varlables such as the output price $P$, the fertilizer price $P_{f}$, and the real interest rate $x, 1 . e$.

$$
\text { (6) } I_{k j t}=I_{k j t}\left(K_{j t-1}, P_{f j t}, \pi_{j t}, B_{j t}, R_{j t}, T_{j t}, \sigma_{j}, \mu_{j}, \epsilon_{j t}\right)
$$

where $R_{j t-1}$ is the capital stock of year $(t-1)$. In these equations the

6/ As discussed in footnote 1, it cannot be estimated either in a reduced form equation of the form of equation (1). 
simultaneity problem between $B_{j t}, R_{j t}$, and $B_{j}$ can be overcome just as for equation (3) by using the flxed effects technique. For the interest rate, however, a smultaneous equation problem may arlse if higher investments demand leads cred1t s ipllers to ralse the interest rate. In the application below this problem is minlmized by the fact that the interest rate used is fixed by the government of Ind1a. Only if the govermmant specifically takes agricultural investment demand (rather then more . aggregate creuit conditions) into account in fixing the interest rate will the simultaneity problem pecsist. For the other prices a simultaneity can also arlse if Increased Investment leads to higher output supply (and. fert111zer demand) and therefore lower output prices (h1gher fert1112er prices). The fertilizer price used below is the rallhead price set by the government and the endogeneity problem is $11 k$ ky to be minimal. However, In order to overcome the simultanefty problem associated with ousput prices we use an index of international comodity prices as an instrumental variable for the domestic price index. As India is a small country in virtually all international agricultural commodity markets, this completely eliminates the simulianeity b1as.7 The Index of International commodity prices is computed separately for each district using district-specific production welghts for the year 1975. Since agricultural wages are clearly endogenously determined with agricultural output and investment we replace this varlable with state-specific urban wages as an instrument.

If India has state trade in agriculture. So the domestic prices do not correspond in any simple way to international prices. Nevertheless, estimates show that domestic prices respond positively to international prices, with a 1 ag of 3 to 4 years. 
As can be seen from figure 1, the varlables entering the aggregate crop supply equations are exactly the same as those entering the investmen: equation and all estimation problems are the same.

Obviously no data exist on the district-specific index of avallable (but not necessarily implemented) technology $T_{j t}$. Evenson and Kislev (1975), BYBM (1986) and others used expenditure data, or manpower data for public research and for extension. (Alternatively Boyce and Evenson (1975) has used research publications). However, data for these variables do not uxist at the district level. Moreover they do not include technology opportunities arising from private industry and seed corporations. Other researchers have used simple time trends to proxy technology opportunities (e.g. Binswanger, 1974). However, simple time trends assume technology opportunities grow at constant and Identical rates in each district. But the point is that agroclimatic endowments affect the extent to which new technology options are applicable to a district. Hence technology trends must differ across districts. If, for example, banks systematicall; located in districts where the green revolution had raised the input and borrowing requirements of farmers, an output supply function including common time trends and banks would erroneously allocate to banks a part of the output contribution of technology, i.e. the coefficient of banks would be upwards biased. In order to circumvent this problem the district specific technology trend is entered into the models as follows:

$$
\text { (7) } T_{j t}=\sum_{m} b_{m} \sigma_{m j} t+b_{t} t
$$

The regression include a common time trend and interaction terms of all the agroclimatic varlables with the time trend, and the district 
specific time trend is an estimated function of time and time $x$ climate interactions. 8 For example in the output supply equation one would. expect the interaction between time and irrigation potential to be positive, consistent because high ylelding varletles of rlce and wheat require good control over water and soll moisture.

\section{Data and Variables}

The data we have used here are drawn from Indla. The crosssection units are 85 randomly drawn districts of Ind1a. These 85 districts belong to 13 states of Indla--Andhra Pradesh, Bihar, Gujarat, Haryana, Janmu and Kashm1r, Karnataka, Kerala, Madhya Pradesh, Maharashtra, Punjab, Rajasthan, Tamil Nadu and Uttar Pradesh. The 85 districts are part of the 99 districts from 17 states randomly drawn by the India's National Council for Applied Economics for its well known Additional Rural Income Survey. 9 The perlod covered in this paper is the agricultural years $1960 / 61$ to $1981 / 82$. The study period covers the agricultural years $1960 / 61$ to $1981 / 82$, but for some dependent varlables with more limited data availability shorter periods are used.

8/ Alternatively one could introduce a trend for each district separately as in Lau and Yotopoulos.

$9 /$ In fact, 80 districts are drawn from NCAER sample, while the remaining 5 districts are the ICRISAT districts. All NCAER districts could not be included because of deficiencles in the data for both primary and secondary districts. 
TABLE 1: Descriptive Statistics of Varlables

Varlable

Dependent variables

Aggregate crop output index

Fert1lizer consumption, nutrient tons/10 sq. $\mathrm{km}$

Net investment in draft animals; numbers per year/10 Sq.Km

Net investment in tractors; numbers per year/10 Sq.Km

Net investment in pumps; numbers per year/10 Sq. $\mathrm{km}$

Net Investment in m11k animals; numbers per year/10 Sq. Km

Net investment in small stocks; numbers. per year/10 Sq. $\mathrm{Km}$

Rural population, numbers/10 Sq. Km

Time-varylng independent variables

Canal Irrigation, '000 ha/10 Sq. Km

Number of villages with primary schools/10 sq. $\mathrm{km}$. 1785

Electr1fled viliages, numbers/10 Sq. Km 1785

Commerclal banks, numbers/10 Sq. $\mathrm{km} 1785$

Regulated markets, numbers/10 Sq.Km 1785

Road length;, $000 \mathrm{~km} / 10 \mathrm{Sq} \cdot \mathrm{Km}$

Real interest rate of cooperative socleties

Aggregate real domestic crop

- price Index

Aggregate Real International Price index

Real urban wage (annual earnings)

Real fertllizer price index

Annual rainfall (In mu)

Time-invariant independent variables

Length of rainy season In months

Number of excess rainy months

Number of cool months

(Temp $\left.<18^{\circ}\right)$

Percentage of district area

llable to flooding

Irrigation potential, percentage

Urban distance $(\mathrm{km})$

Soll molsture capac1ty Index
Number of

Observations
Mean

Standard

Deviat1on

1.045

924.045

15.504

0.260

1.864

1.343

13.555

25.489

15.291

5.308

1547.327

1785

1785

1785

1785

1785

1785

1785

0.064

0.099

1.139

0.688

0.605

0.764

0.069

0.108

0.014

0.022

4.277

4.485

4.010

0.968

0.295

0.687

4186.336

3.413

1138.573

0.355

1195.586

0.505

986.503

85

85

1.368

1.393

$1.313=$

85

85
1.236

0.935

1.389

30.001

298.441 .

2.350 
For each district the aggregate crop output is the index of 20 major crops with district-specific prices of $1975 / 76$ as the base. Agricultural investment is represented by private investment in draft animals, milk animals, small stock (1.e. sheep and goats), tractor, and Irrigation pump. Investment for each perfod is the difference in the stocks measured for each of the agricultural censuses which occurred at five year or six year intervals. It is therefore net investment per year during each of four intercensal intervals. Government infrastructure consists of primary schoois, canal irrigation, rural electrification, regulated rural markets, and total road length. The only. rural financial Intermediary is the number of rural branches of Commerclal Banks--the only comparable data avallable for the study period 1960-81. The variables that characterize the district's agroclimate environment are the irrigation potential, the length of the rainy season in months, the number of months in a year with excessive rain (where rainfail exceeds potential evapotranspiration), 10 the number of cool months in a year when mean temperature is less than 18 degree Farenhelt (this is related to the ability to grow wheat), the proportion of a district liable to flooding, an Index of the molsture capacity of the solls in the district, and the district's distance to the nearest major urban center (out of eight centers 1.e., Delh1, Bombey, Madras, Banglore, Kanpur, Ahmedabad, Hyderabad and Calcutta). The price variables consist of the annual per capita earnings of industrial workers as a proxy for urban wages, a price Index of fertilizers at railheads, the rate of interest charged by the Primary Agricultural Cooperative Societies, and the district specific real

10/ Evapotranspiration is a sum of transpiration via plants and evaporation from so11. 
International price Index for the aggregate output. The international prices of 17 crops have been converted to Rupees at the officlal exchange rate and aggregated using district-specific production weights for the agricultural year 1975/76. Domest1c price indices using district level farm harvest prices have also been computed for comparison. All the prices or price Indices are deflated by the consumer price index for rural workers using $1975 / 76$ as the base year. The interest rate charged by cooperative credit societies is the expected real rate $1 . e .$, the nominal rate for the current year less the average percentage increase in the consumer price Index for the previous five year, 1.e. inflationary expectations are assumed to form over a flve-year perfod. 11 The means and standard deviations of these varlables are listed in table 1.

- The data relating to the agroclimate and the urban distance are single data points for each of the 85 district, because they are the permanent characteristics of each district. The data relating to agricultural output, government Investment, prices and Commercial Banks are time-serles data covering the period, 1960/61-1981/82. In contrast, the Investment data refer to the four Intercensal periods 1961-66, 1966-72, 1972-77, 1977-82. When investment equations are estimated the independent variables are their respective means over the corresponding census Intervals.

$11 /$ In both the output supply and investment equations, the Inflation rates are averaged over five years, except for the years prior to 1965 where data limitation led us to use averages for 2,3 and 4 years respectively. The rate of inflation did not fluctuate sharply in the late fiftles, or early sixtles. 
The following variables require additional explanation: The aggregate output index reflect both varlation over time in each district relative to its base year 1975 as well as varfations in output across districts relative to a hypothetical average district formed by computing the averages of all varlables across districts in 1975. The agregate output is normalized for district size, 1.e. it impares aggregate "ylelds" per unit of geographic area. When fixed effect techniques are used the across- di-trict variability is of course lost.

Regulated markets do not include all rural markets but only those where government provides market infrastructure and regulates all trades via a supervised auction system. The government does not regulate the market price but may enter as a purchaser in order to prevent market priceṣ from falling below its guaranteed level.

The rural banking system is complex. It consist of traditional moneylenders and traders for whom no data exist. Cooperative credit socletles were the first formal institutions to achieve wide rural coverage. They lend largely for short-term production purposes such as fertilizers. By 1969 such societies existed in virtually all districts of India covering 94 percent of the villages in the country and they were providing $5 i$ percent of total formal credit extended to famers. Their number has been declining as smalier societies have been merged in recent years. Yet by 1979 they were providing 49 percent of all formal credit. We include the regulated government lending rate of these societies among the explanatory variables. At this regulated interest rate credit rationing is pervasive and we test whether the rate has an influence on 
output and investment despite the rationing. Land Development Banks are also cooperative institutions which lend primarlly for investment purposes. Between 1969 and 1979 their share of lending in formal credit increased from 15 percent to 19 percent. Their lending rates are closely tied to the offlclal rates of the Cooperative Credic Socleties, 1.e. the Interest. variable will capture the effect of Interest rate changes of both the cooperative credit societies and the Land Development Banks.

The Commerclal Banks, in 1960, were not involved in lending to farmers except perhaps to plantations and very wealthy farmers. However, they did considerable lending to agroindustrial enterprises. After their nat: nalization in 1969 they were compelled by the government to expand. their lending to farmers and agrolndustry with targets set both for number of rural branches as well as the proportion of lending to the agricultural sector. Between. 1969. and 1979 the share of comercial banks in formal credit provided to farmers rose from 34 percent to 49 percent at the all India level. In the 85 districts considered here the role of commercial banks rose even farther. Thei- share in formal credit rose from 52 percent In 1972 to 72 percent in 1979. At the same time the number of rural and. seml-urban commercial bank branches rose from 3,625 to 7,690 . Unlike the volume of lending and outstanding loans in any period, which is influenced by farmer demand, the number of branches is strictly controlled by the Banks and therefore strictly exogenous to farmer decision making. Other than for the joint dependence of farmer and bank decision making on agroclimatic and Infrastructure varlables, no endogeneity problem therefore arises. Unfortunately the number of Cooperative Socleties and Land Development Banks cannot be used in these equations as exogenous measure of the growth of these systems because the process of consolidation has 
-reduced their numbers but not necessarily the avallabllity of their services in the affected villages.

Soll molsture capac1ty is a varlable which can be vlewed as a substitute for either rainfall or irrigation. For a given rainfall a higher soll molsture capacity means that a crop can withstand more days without additional rafnfall. In addition where soil molsture capacity is yery high, a full moisture reservolr in the soll may be able to support several months of a crop cycle without the addition of rainfall or .Irrigation. For given annual rainfall, payoffs to irrigation investments are therefore more limited where soll molsture capacity is higher.

Irrigation potential is defined as the percentage of a district's area Inside any type of Irrigation command area, 1.e.. sum of proposed. command area, command area under construction and already existing comnand area. 12 This variable has been measured using the Irrigation Atlas of India. Planned command aress are a good indicator of the remaining potential for canal Irrigation in India as they reflect long range plans and any area not yet included in these plans has virtually no potential.

IV. Agroclimatic Endowments, Infrastructure, Population and Crop Output

In Table 2 we see that the seven measured agroclimatic and location factors explain between 24 percent of the variation in the density of primary schools to 41 percent of the variation in government provided

12/ An irigation command area is an area which receives or is expected to recelve water from an irrigation system. 
Table 2: Effecte of Arreclimate Endownente on Int reatructure, Population

and Arregate Crop output

(Observation $=85)$

\begin{tabular}{|c|c|c|c|c|c|c|c|}
\hline $\begin{array}{l}\text { Explanatory } \\
\text { Veriables }\end{array}$ & $\begin{array}{l}\text { Rurel } \\
\text { Roed }\end{array}$ & $\begin{array}{l}\text { Regulated } \\
\text { Uerket }\end{array}$ & $\begin{array}{c}\text { Canol } \\
\text { Irrigation }\end{array}$ & $\begin{array}{l}\text { Primery } \\
\text { Sehool }\end{array}$ & Electricity & $\begin{array}{c}\text { Rurel } \\
\text { Population }\end{array}$ & $\begin{array}{l}\text { Aggregete } \\
\text { Crop Output }\end{array}$ \\
\hline Cool months & $\begin{array}{c}-6.222 \\
(-6.687)\end{array}$ & $\begin{array}{c}0.684 \\
(1.647)=\end{array}$ & $\begin{array}{c}0.622 \\
(1.659)\end{array}$ & $\begin{array}{c}0.308 \\
(4.770)\end{array}$ & $\begin{array}{c}0.380 \\
(4.293) *\end{array}$ & $\begin{array}{l}286.726 \\
(2.281)=\end{array}$ & $\begin{array}{c}0.229 \\
(2.417) *\end{array}$ \\
\hline Excese roin & $\begin{array}{c}0.229 \\
(0.477)\end{array}$ & $\begin{array}{l}-6.602 \\
(-6.751)\end{array}$ & $\begin{array}{c}-0.601 \\
(-0.887)\end{array}$ & $\begin{array}{l}-0.041 \\
(6.077)\end{array}$ & $\begin{array}{l}.000 \\
(2.079)\end{array}$ & $\begin{array}{l}425.138 \\
(2.679)\end{array}$ & $\begin{array}{c}0.019 \\
(0.158)\end{array}$ \\
\hline Reiny season & $\begin{array}{l}2.442 \\
(4.021)=\end{array}$ & $\begin{array}{c}-8.004 \\
.(-6.146)\end{array}$ & $\begin{array}{c}0.007 \\
(0.708)\end{array}$ & $\begin{array}{c}0.070 \\
(0.088)\end{array}$ & $\begin{array}{c}0.680 \\
(0.776)\end{array}$ & $\begin{array}{c}541.380 \\
(3.386)\end{array}$ & $\begin{array}{c}0.264 \\
(2.206) *\end{array}$ \\
\hline Flood potential & $\begin{array}{c}-0.077 \\
(-0.609)\end{array}$ & $\begin{array}{l}-0.001 \\
(-1.022)=\end{array}$ & $\begin{array}{c}-0.024 \\
(-1.234)\end{array}$ & $\begin{array}{c}0.021 \\
(0.862)\end{array}$ & $\begin{array}{l}-0.004 \\
(-1.025)\end{array}$ & $\begin{array}{l}-10.840 \\
(-0.220)\end{array}$ & $\begin{array}{l}-6.604 \\
(-2.674)\end{array}$ \\
\hline $\begin{array}{l}\text { Soil moiature } \\
\text { espacity }\end{array}$ & $\begin{array}{c}0.422 \\
(1.670)\end{array}$ & $\begin{array}{c}0.094 \\
(2.827)\end{array}$ & $\begin{array}{l}-0.610 \\
(-2.187)\end{array}$ & $\begin{array}{c}0.116 \\
(2.159) *\end{array}$ & $\begin{array}{c}0.231 \\
(-0.082)\end{array}$ & $\begin{array}{r}-140.635 \\
(-6.684)\end{array}$ & $\begin{array}{c}0.102 \\
(0.914)\end{array}$ \\
\hline Urban distance & $\begin{array}{c}-0.608 \\
(-0.118)\end{array}$ & $\begin{array}{r}0.00004 \\
(2.381)=\end{array}$ & $\begin{array}{c}0.0001 \\
(2.266) *\end{array}$ & $\begin{array}{r}-6.0602 \\
(-6.320)\end{array}$ & $\begin{array}{c}-0.061 \\
(-1.419)\end{array}$ & $\begin{array}{c}-0.071 \\
(-0.025)\end{array}$ & $\begin{array}{c}0.084 \\
(0.026)\end{array}$ \\
\hline Constant. & $\begin{array}{l}-4.218 \\
(-1.602)\end{array}$ & $\begin{array}{c}-0.014 \\
(-0.978)\end{array}$ & $\begin{array}{c}-6.618 \\
(-6.384)\end{array}$ & $\begin{array}{c}0.588 \\
(1.474)\end{array}$ & $\begin{array}{c}0.186 \\
(0.326)\end{array}$ & $\begin{array}{r}-416.025 \\
(-0.624)\end{array}$ & $\begin{array}{c}-0.804 \\
(-1.352)\end{array}$ \\
\hline Adjusted R-equer & re 0.37 & 0.38 & 0.48 & 0.24 & 0.28 & 0.41 & 0.63 \\
\hline
\end{tabular}

Not.1E: t-Stetiatics are in perentheses. Astariak rofors to eignificance lovel of 18 parcent or better. Rursl road corresponds to the egricultural yoer 1974, while the reanining variables relato to egricultural year 1981 . 
irrigation and the population density of the region. The explanatory power is thus very substantial, not much smaller than that for output itself (53 percent). The traditional treatment of agricultural infrastructure as exogenous variables in output supply analysis is unwarranted.

The variable with the most powerful effect across the equarions is irrigation potential, 1.e. the proportion of the area which is included in an exlsting or planned 1rrigation command area. It significantly Increases the density of all infrastructure variables, except schools. It is also clear that population has migrated to, or grown more rapidly in regions with a high irrigation potentlal, 1.e. private and public decisions are influenced by the same factors:

For the other variables the impact varies substantially across the government investments. Regions with a falrly cool winter, which are able to grow wheat, have higher density of regulated markets, more primary schools, more electrification and higher population density. Population density is also very high in reglons with many wonths with excess rain, i.e. the humid tropical zones such as Kerala. Population and roads are higher the longer the rainy season, or sald otherwise, government has found it less worthwhile to build roads in semiarid and arid regions. Areas which are liable to flooding are not well served by regulated markets, roads, and electrification. As discussed in the data section, the results show that high soll moisture capacity acts as a substitute for canal irrigation. But high soil moisture capacity is a posttive agroclimatic attribute and thus attracts investment in regulated markets, roads and in electrification. Distance to major urban centers tends to Increase the 
Distance to major urban centers cends to increase the density of regulated rural markets, and also the level of goverment provided irrigation.

One point which stands out from the regressions is that for the purpose of government infrastructure investments, agroclimat1c potential cannot be measured by a single variable or an agroclimatic index. Different aspects of the endowment affect the government investments differentially.

The total effects--both direct and indirect effects via government Infrastructure and banks--of agroclimate and location factors on output supply are also shown in table.2. They suggest that agroclimatic endowments explain 53 percent of the variation in agricultural production of 85 districts in the agricultural year, 1981. Agricultural output supply is high in regions well endowed with water from either irrigation or rainfall. Regions with a relatively cool winter have high agricuitural output while agricultural output is low in reglons with a high flood potential. All the effects are as expected.

Using data for the three.census years $(1961,1970,1981)$ we investigate in table 3 whether the investment trends over the past two decades were similiarly influenced by the agroclimatic characteristics. This is done in regressions which include time trends according to equation7, 1.e. interactions between time and the agroclimatic characteristics. The Hausman-Wu test suggests that a fixed effects model is appropriate for explaining variation in public infrastructure over time, while a random effects model can be used for rural population growth. 
TABLE 3. Effocte of Agroclimate Endowmonts on Growth in Infrastructure and Population.

$$
\text { (Ob. 255) }
$$

\begin{tabular}{ccccc}
$\begin{array}{c}\text { Explanatory } \\
\text { Variable }\end{array}$ & $\begin{array}{c}\text { Regulated } \\
\text { Merket }\end{array}$ & $\begin{array}{c}\text { Conol Irpigation } \\
\text { Frimory }\end{array}$ & $\begin{array}{c}\text { Rehool Rural } \\
\text { Electrification Population }\end{array}$ \\
\hline
\end{tabular}

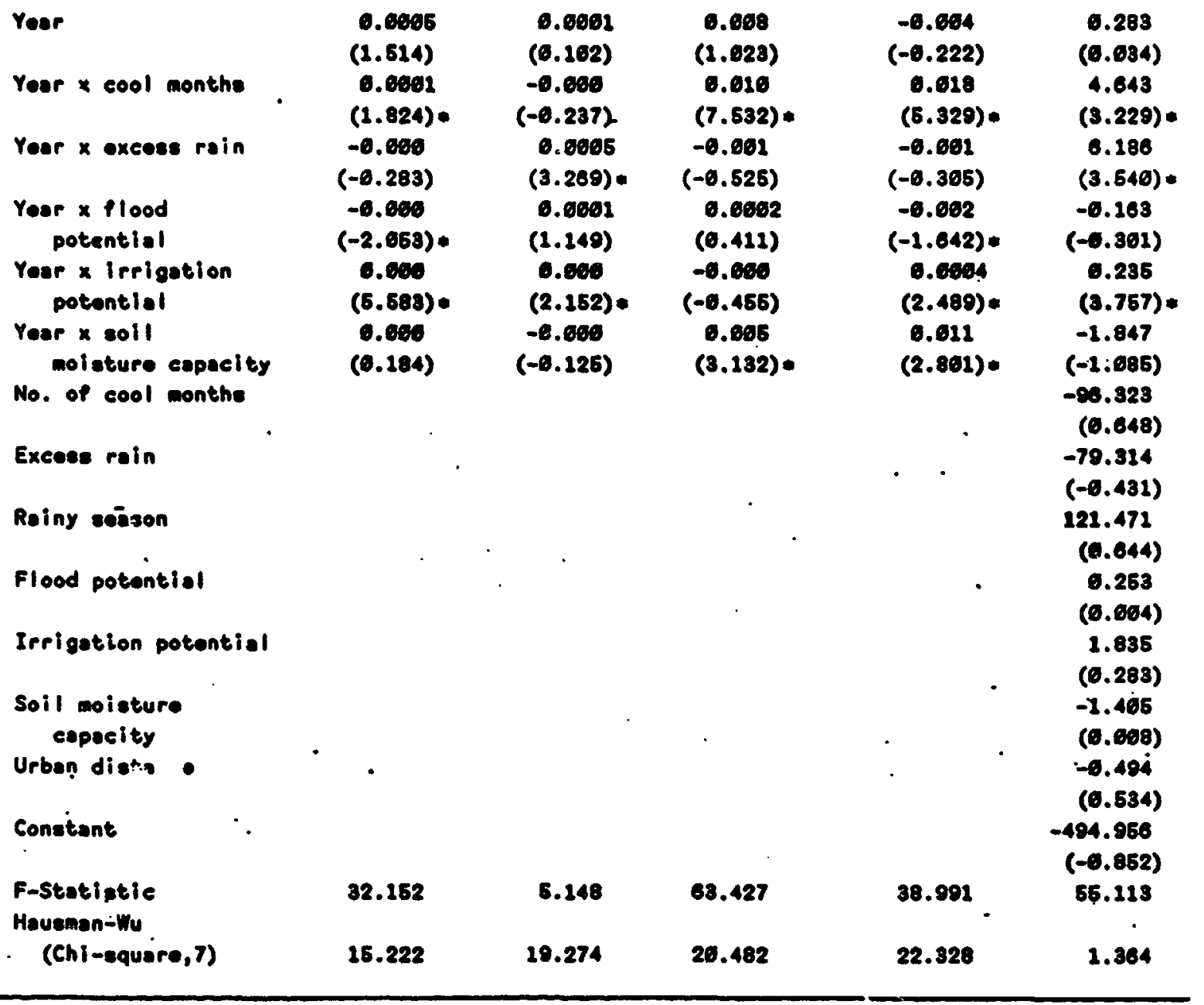

Note: Aatoriak rafors to olgnifieance level of 20 porcent or bottor on two-tell teat. 
The results are consistent with the simple cross section results. They suggest that better agroclimatic attributes such as irrigation potential contribute to the growth in public infrastructure as well as population, while unfavorable attributes such as flood potential reduces their growth over time. This clearly indicates that agroclimatic endowments did not only affect the placement of public programs and institutions in the distant past, but also their growth over the study period.

\section{v. Development of Commerclal Banks}

In Table 4 the cross-section results Indicate that Commercial Banks have tended to locate in areas which are well endowed with water, either from irrigation or from a long and over-abundant rainy season. Such areas are characterized by relatively low risk of agriculture and therefore less repayment problems for the banks (Binswanger and Rosenzweig, 1986). Th. implies that the banks have avolded areas where drought risk is high. That banks try to avoid high-risk areas, is also apparent in the negative coefficient. of flooding potential.

The simple cross section relation for the year 1980 included the indirect effects of the agroclimate on Bank, via the improved infrastructure. The pure infrastructure effects, on the other hand, are estimated and presented in Table 4 using the cross-section time-series data of 85 districts for the years 1972-80. As the results of the Hausman-Wu test suggest, the fixed effects model appears more appropriate than the random effects model in explaining the variation in the bank growth over time and only the fixed effects results are therefore shown. The 
TABLE 4: Effects of Agioclimatic Endowments and Government Infrastructure on Commercial Bank

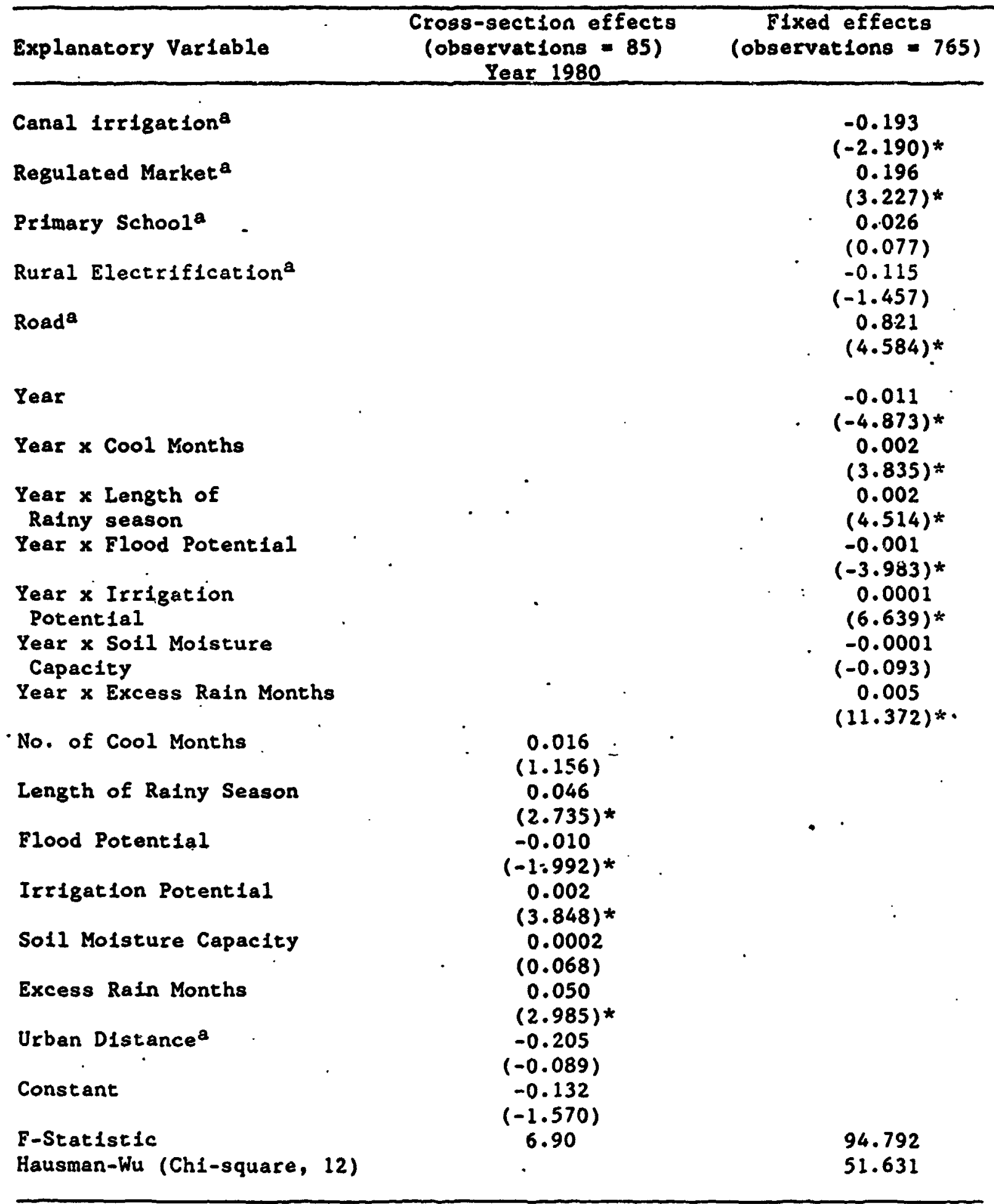

NOTE: t-Statistics are in parenthesis. Asterisk refers to significance level of 10 percent or better.

a Coeficients of these variables are in elasticity form. 
regression clearly shows that Banks are more 11kely to locate in areas where the road infrastructure and the marketing system are improving. Markets provide both higher Incomes to producers and reduce the price risk they face, 1.e. they Improve the1s repayment capac1ty. And roads have an eifect on farmer Income, demand for Inputs and hence credit and they reduce the credit transactions costs of both the customers and the banks. of the two varlables, roads have the most powerful effect with an elast1city of about 0.83 , followed by regulated markets with an elasticity of 0.20 . Markets, of course, are a relatively cheap investment which can be increased much more rapidly than roads. Rural electrification does not. contribute to Bank grouth. Indeed 1t has a negative effect which is statistically signiflcant at the 10 percent level.

The time trend and the interaction effects with time confirm that Bank growth has been more rapid in districts with a high irrigation potential, where the rainy season is longer, and where cool months allow for the growth of wheat. This is fully consistent with the hypothesis that banks have systematically located in environments which were favorable to the green revolution technologies; 1.e. that banks responded to opportunities.created by technical change. In add1tion bank grówth was lower where the flood potentially high, 1.e. where.they face higher risk and where green revolution technology is less applicable because of lack of water control.

\section{vI. Determinants of Private Investment}

The investment data in table 5 relate to average annual levels of Investment for each of the intercensus intervals for which we have data. 
Table 5. Effects of Agroel limatic Endommente, Covernment Inf raetructure, Commercial Bank and Prices on Agricultural Investment

$$
\text { (No. of Observations }=304 \text { ) }
$$

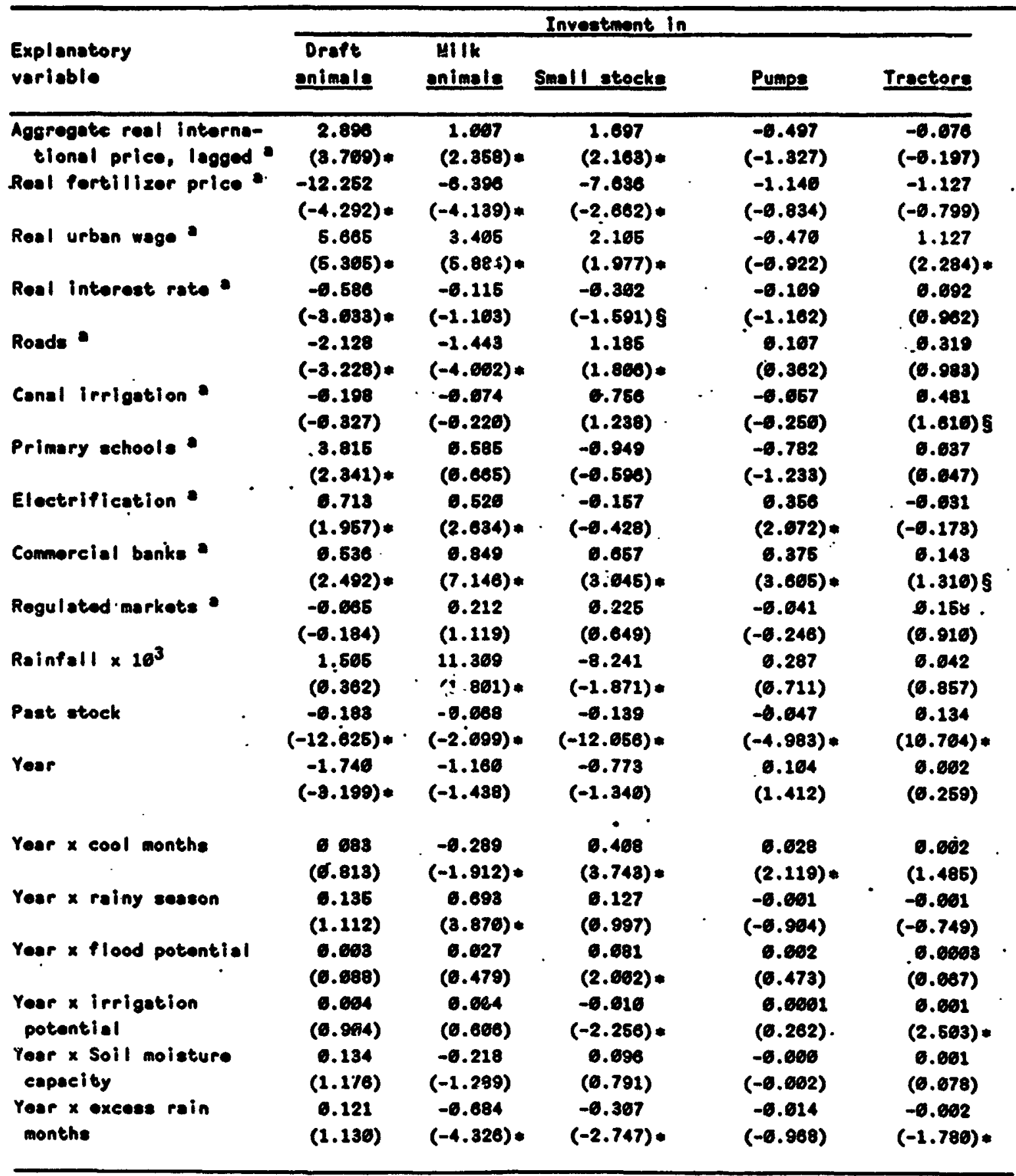


CONT'D

\begin{tabular}{|c|c|c|c|c|c|}
\hline \multirow[b]{2}{*}{$\begin{array}{l}\text { Explanatory } \\
\text { veriable }\end{array}$} & \multicolumn{5}{|c|}{ Investment in } \\
\hline & $\begin{array}{l}\text { Draft } \\
\text { enimole }\end{array}$ & $\begin{array}{l}\text { Milk } \\
\text { enimole }\end{array}$ & Small tocks & Pumpe & Tractors \\
\hline Length of rainy sesson & $\begin{array}{c}-4.362 \\
(-0.481)\end{array}$ & $\begin{array}{l}-48.948 \\
(-2.891)\end{array}$ & $\begin{array}{l}-10.126 \\
(-0.984)\end{array}$ & $\begin{array}{c}-0.090 \\
(-6.683)\end{array}$ & $\begin{array}{c}0.080 \\
(0.388)\end{array}$ \\
\hline Flood potentiel & $\begin{array}{c}-0.781 \\
(-6.218)\end{array}$ & $\begin{array}{l}-2.918 \\
(-8.689)\end{array}$ & $\begin{array}{l}-5.104 \\
(-2.324)\end{array}$ & $\begin{array}{c}-0.133 \\
(-6.825)\end{array}$ & $\begin{array}{l}-0.001 \\
(-0.017)\end{array}$ \\
\hline Irrigation potentiel & $\begin{array}{c}-6.687 \\
(-6.698)\end{array}$ & $\begin{array}{c}-0.211 \\
(-0.300)\end{array}$ & $\begin{array}{c}-0.018 \\
(-0.088)\end{array}$ & $\begin{array}{c}-6.615 \\
(-6.342)\end{array}$ & $\begin{array}{l}-0.012 \\
(-2.390)\end{array}$ \\
\hline So:l moisture cepecity & $\begin{array}{l}-14.280 \\
(-1.376)\end{array}$ & $\begin{array}{l}10.785 \\
(6.689)\end{array}$ & $\begin{array}{l}-14.376 \\
(-1.277)\end{array}$ & $\begin{array}{c}6.283 \\
(0.239)\end{array}$ & $\begin{array}{c}0.002 \\
(0.013)\end{array}$ \\
\hline Excess rain monthe & $\begin{array}{l}-4.844 \\
(-0.484)\end{array}$ & $\begin{array}{l}48.592 \\
(3.352)=\end{array}$ & $\begin{array}{l}16.888 \\
(1.620)\end{array}$ & $\begin{array}{c}0.707 \\
(0.835)\end{array}$ & $\begin{array}{c}0.155 \\
(1.357)\end{array}$ \\
\hline Urban distance & $\begin{array}{c}-6.036 \\
(-6.84 \theta)\end{array}$ & $\begin{array}{c}-0.080 \\
(-0.459)\end{array}$ & $\begin{array}{c}-0.082 \\
(-1.821)\end{array}$ & $\begin{array}{c}-0.604 \\
(-1.243)\end{array}$ & $\begin{array}{r}-8.6903 \\
(-6.528)\end{array}$ \\
\hline No. of cool monthe & $\begin{array}{c}1.052 \\
(c .104)\end{array}$ & $\begin{array}{l}25.048 \\
(2.623)=\end{array}$ & $\begin{array}{l}-21.481 \\
(-2.321)\end{array}$ & $\begin{array}{l}-2.007 \\
(-2.024)\end{array}$ & $\begin{array}{l}-0.113 \\
(-1.161)\end{array}$ \\
\hline Constant & $\begin{array}{c}178.718 \\
(8.319)=\end{array}$ & $\begin{array}{r}121.798 \\
(1.489)\end{array}$ & $\begin{array}{l}108.410 \\
(3.801)\end{array}$ & $\begin{array}{l}-1.466 \\
(-0.229)\end{array}$ & $\begin{array}{c}-6.092 \\
(-6.068)\end{array}$ \\
\hline $\begin{array}{l}\text { F-stotiotie } \\
\text { Heusmen-Wu }\end{array}$ & 16.188 & 20.951 & 8.070 & 4.282 & 21.600 \\
\hline (Chi-equere; $19 \mathrm{df}$ ) & 29.868 & 16.426 & $21.10:$ & 10.674 & 11.180 \\
\hline
\end{tabular}

Notes: t-statistice are in parenthesis. Asterisk rofers to significence level of 10 porcent or bottor on i two-toil tost.

- Coefficients of these variables ere in elasticity form.

5 rofors to eignificence level of 10 pereant or botter on aingle-tail tost. 
The independent variables similarly are the means for the intercensal periods of the corresponding data. Unlike in the banking equation wizich used annual data and where flxed effects model were approprlate, the random effects model is not rejected for the investment equations which used four census data.

The lagged price of aggregate crop output (1nstrumented by the aggregate international price index) has a positive effect on three of the classes of investment (draft animals, milk animals and small stocks). For the animals the elasticities of investment with respect to price are between 1.0 and $2.9,1 . e$. much higher than typical values of output supply elasticitles for Individual crops. But note that these elasticities are investment elasticities and Investment can be postponed and is therefore much more volatile than current planined output. The elasticities of the Investment equations can therefore not be directly compared to output supply elasticities. An increase in the price of fertilizer reduces private investment of all categorles although the effect is not statistically significant for pumps and tractors. If an investment good, for example, draft ąnimals were a substitute for fertilizer we should see a - positive substitution effect. But an Increase in fertilizer price also means reduced farm profits and perhaps reduced liquidity, resulting in a negative effect on investment. The negative fertilizer price elasticities of the investments suggest that the negative profit or liquidity effects dominate the positive substitution effect of fertilizer price increases.

If the urban wage measures the opportunity cost of labor in agriculture, then its increase means both a positive cross-price effect (if labor and capital goods are substitutes in production) and a negative 
profitability effect on farm capital investment. Unlike for the fertilizer price, the positive substitution effects appear to dominate the negative profit effects.13 The results suggest that a 10 percent increase in urban wages would Increase annual Investment (not capital stocks) In draft animals by about 57 percent, and in tractors by about 11 percent, m11k animals by about 34 percent, and small stocks by 21 percent. RIsing interest rates have..negative effects on draft animals, milk animals, small stocks and pump investments, but only the effects for draft animals and small stock are statistically significant. Overall the price-and Interest variables are seen to Influence investment decisions in the expected direction.

of the infrastructure variables the expansion of the commercial. bank branches appears to most clearly accelerate the pace of private agricultural investment. A 10 percent increase in the number of copmercial - bank branches increases investment in animals and pumpsets by between 4 to 8 percent. The effects on tractors is 1.4 percent. These are substantial effects of bank expansion on investments.

A 10 percent increase in electrifled villages increases investment into pumps (which are often driven by electriclty) by 4 percent. Barnes and Binswanger (1986), using fixed effects technique with Indian village data, also found that electricity tended to increase the number of pumpsets

13/ The effects of urban wage may also capture the impact of an exogenous increase in urban income on the demand for agricultural output. These effects are expected to be positive which then only reinforce the positive substitution effects. 
In the villages. The increase in electrification is also seen to spur Investment in draft and milk animals by 7 and 5 percent respectively. These are effects of electrification which had not previously been demonstrated.

Canal irrigation should not be expected to reduce any of the Investments, except for that pumpsets, which can be substituted for canal irrigation. The results suggest that canal frrigation increases investmen: in tractors with an elasticity of 0.48 . The estimated positive effect on small stocks Investment is not statistically significant.

The effects of road expension on investments are not very convincing as roads appear to reduce investment in draft and milk animals and increase investment in small stocks. This may partly be because the growth data for roads is derived from state level statistics and does not differ across the districts within a state. (However the level data for roads for $\cdot 1974$ were avallable). Neither is it possible to show any effect for regulated markets. Primary school expansion increases draft animal Investment, while favorable rainfall within the census interval increases only investment in milk animals.

The only coinparable study using fixed effects techniques is the BYBM study of tractor stocks which include a number of similar explanatory. varlables. Unlike in the present study aggregate prices (both crop and livestock) tend to increase tractor stocks with an elasticity of 0.16 . Fert1lizer prices also reduced tractor stocks while urban wages increased it (but not significantly). Again in contrast to the current results roads and irrigation both had statistically significant positive effects on tractor stocks. 
The investment equations include the past stocks of the capital Item. Except for tractors, the higher the past stocks, the lower the current Investment, 1.e., there 1s clearly stock adjustment. For tractors, on the other hand, Investment is much more rapid where past stocks are larger. Tractor stocks were very small in India in 1961, with an average of only 0.14 tractors per $10 \mathrm{sq} . \mathrm{km}$. By 1982 this number had risen to 2.58. Unlike for the other capital 1tems the tractor equation includes. both technology adoption and investment phenomena. The adoption process has not yet run 1ts full ccurse. It is therefore not surprising to see. districts with an early lead in tractor stocks experfencing higher rate of adoption-cum-investment, as an early lead may indicate better development of the supporting sales and service infrastructure which is not measured.

The investment equations include the agroclimatic characteristics themselves and their interaction with time. Together with the time trend the interaction terms form the district-specific time trends. From the interaction terms we can therefore see that investment in all items except milk animals grew more rapidly in areas with more cool months, consistent with a strong response of private investment to the green revolution in wheat.

- Tractors investment was less in areas with excess rain but more rapidly in districts with a high irrigation potential, 1.e. areas where on account of double cropping demand for tractors is particularly high. Milk animal investmenc was higher where the rainy season was longer while smallstock, i.e. sheep and goats grew less in areas with high moisture either from irrigation or from excess rain. 
The pure effects of agroclimate variables themselves are their net impacts other than via their impact on growth of infrastructure, changes in prices or new technology. If investment tends to eventually bring capital stocks into equilibrium with respect to agricultural opportunities, net Investment should become zero in the absence of other changes and no effect of the agroclimatic factors should show up. This tendency can indeed be seen in the resulting coefficients: only 7 out of a total of 35 are statistically significant. This compares to 10 statistically significant effects of the interaction terms with time (out of the same total of 35 ). Since the expected sign of the agroclimatic variables in the investment equations is zero, it is not worth interpreting them.

VII. Determinants of Fert1lizer Demand and Aggregate Crop Output

For fertilizer demand and output supply the fixed effects model has to be used. The measured permanent district characteristics are therefore not sufficient to fully characterize the endowment of a district. Fertilizer demand is seen to decline significantly when the price of fertilizers is increased (elasticity of -0.57 ) and to increase when the urban wage rises (elasticity of 0.13 ). This effect is statistically significant if the approprlate one-tail test is used, as it makes no sense to expect a negative sign here. In contrast, we see a perverse positive interest elasticity, but the effect is. not statistically significant.14 A positive interest rate effect may indicate that there is still an 
unresolved simultaneity problem with respect to this variable if government responds to higher demand for fertilizers by increasing the rate of interest. Fert11izer demand Increases with all infrastructure investments, although effect of canal irrigation is not significant. The effects of primary schools, regulated markets and commercial banks are particularly large and precisely estimated.

These extremely clear results accord fully with what is known from other studies of the growth of fertilizers. To the previous literature they add the first estimates of the Impact on fert1lizer demand of changes In the rural bank network.

Finally the agroclimate $x$ time Interactions accord very well with what what is known about the influence of agroclimatic endowments on the . potential of green revolution technologies, with fertilizer demand growing especially fast in green revolution areas with cool months, 1rrigation or high soil molsture capacity, while being held back in areas of excessively high rainfall and poor water-control.

In order to 1ilustrate the endogeneity problem of using domestic prices in explaining aggregate crop output we present results with both the domestic and the international price indices. The comparisons clearly show that an endogeneity problem is being circumvented when prices are instrumented via the international price index. The coefficient of the domestic price is only 0.06 while that with the international price is 0.24. Moreover, the aggregate crop supply elasticity of 0.13 estimated with the international price exceeds the elasticities estimated for India In BBQ and that estimated for the world In BYBM by a factor of 1.5 to 2. 
Table 6. Fixed Effects of Government Intrestructure, Commerciel Bank and Prices

on Fortillizer Demand and Aggregate Crop Output

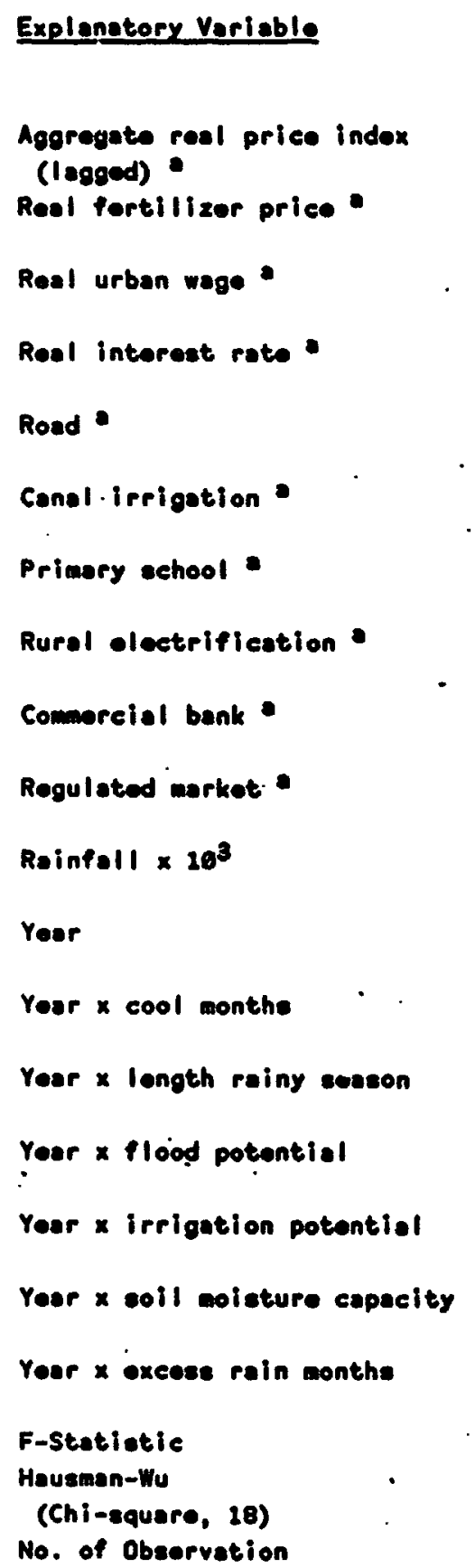

\section{Fertillzer Denend}

0.056
$(1.049)$
-0.572
$(-3.484)$
0.125
$(1.424) 5$
0.625
$(1.368)$
0.224
$(1.780)$

0.659

(6.638)

1.498

(6.201)

0.805

(1.889) 8

0.247

(0.687)

0.488

(6.687)

1.278

(1.252)

$-2.238$

$(-5.368)$

0.287

(2.808) *

$-0.697$

(-0.676)

$-0.684$

(-1.247)

0.928

(6.781)

0.670

(6.680)

$-0.398$

$(-4.305)$

79.957

42.918

1148
Arrerate Crop Output

Domestic Prices Internotional Prices

0.645
$(1.804) 5$
0.621
$(0.435)$
0.658
$(1.548) \S$
6.004
$(0.042)$
6.215
$(6.063)$
0.038

0.180

$(8.472)$

$-9.117$

$(-2.320)$

0.653

$(1.491) 6$

$-0.001$

$(-0.262)$

0.261

6.093

$(0.649)$

(2. 830$)$

0.628

(0.827)

0.381

(4.216) *

0.835

(4.322) *

0.681

0.628

(2.746) *

(1.603) 8

0.618

(1.766)

0.628 .

(1.018)

0.979

0.084

(4.627)

(4. 972$)$

0.073

0.071

(3.482) =

(3. 458)*

$-6.010$

$(-8.179)$

0.086

$-0.026$

$(-4.299)$

(4.891)

0.008

(4.816) .

$-6.068$

$-6.603$

$(-2 . \cdot b)$

$(-1.989)$ *

$-0.001$

$-6.001$

$(-3.716)$

0.001

$(-8.679)$

$(12.448)$

0.601

(12.067)

0.005

(4.324) =

$-0.005$

(3.792)

$-0.604$

$(-3.549)=$

$(-3.686)=$

98.864

183.936

16.300

44.754

Notes: t-statistics ore in poranthesis. Astorisk rafors to significance level of 10 porcent or bettor on a two-tail test.

- coofficients ore in elasticity form.

5 refore to 10 porcent lovel of significance on a one-tall tost. 
Nevertheless, the classic result of the aggregate supply elasticity

literature is reconfirmed: short-run aggregate crop supply elasticities are sma11 and do not exceed a level of 0.2 .13

The endogenelty problem with the output price also affects the estimation of the fertilizer price elasticity. Using the domestic output price the fertilizer price does not appear to affect aggregate output. In the specification using international output prices the fertilizer price elasticity is negative $(-.12)$ and statistically significant. The results are consistent with BYBM (1986) and BBQ (1984). The remaining discussion w111 therefore only consider the results with the international price.

Increasing real interest rates of the cooperative sector reduces aggregate output marginally an elasticity of about -0.001 , while increasing the density of commercial banks tends to increase crop output with an elasticity of 0.020 . The expansion of financial institutions thus seems to exert a direct impact on aggregate crop output and a larger effect in fertilizer demand as. well as on some of the private agricultural investments.

Except for 1rrigation, all other infrastructure varlables affect aggregate crop output positively. The overwhelming impact of Infrastructure on aggregate crop output found in BYBM for international

$13 /$ We attempted to estimate the long-run aggregate elasticity of supply with this data set, using a free form lag structure of five past prices. The sum of the coefficients was .28 , and we could not, with this technique, estimate a larger long-run aggregate supply response. However, long-run supply responses must be-larger, as discussed in BYBM. 
dasa is thus confirmed in this Indian study. Quantitatively the effects of primary schools and roads are the largest, with elasticities of 0.34 and 0.20 respectively. BYBM found large effects for education as well. They also found large 1rrigation effects but irrigation in the BYBM study Include both private and canal irrigation.

As expected residual growth of output (after account is taken of prices, interest rates, infrastructure and banks) was larger in areas with good irrigation potential, high soll molsture capacity, and cool winters. - It was lower in areas with excess rain and in areas liable to flooding.

\section{Discussion}

In the paper we have successfully demonstrated that with approprlate panei data it is possible to overcome simultaneity and unobservable variable problems arising from the folnt dependence of the decision of farmers, financial institutions and government agencies on location and agroclimatic factors of the region within they operate. It then becomes possible to explain in an integrated fashion how the decision of these actors Interact and ultimately affect agricultural investment and output. In addition, by judiciously using international prices we have shown that it is possible to overcome simultaneity problems which have long plagued the analysis of aggregate supply response to output prices.

The reduced form regressions of infrastructure, banks, investments and output on agroclimatic and location characteristics show the overwhelming importance these factors which must have had over the history of these districts on all decision-makers in the system. The importance of 
the Interaction terms with time shows that the agroclimate factors have continued to govern the rate at which districts can take advantage of new agricultural opportunities and have continued to govern public, bank and private investment allocation decislons over the perlod analyzed.

For the first time this paper presents results on the effect of the expansion of financial intermediation on agricultural investment and output which are not seriously flawed because they ignore fungibility of financlal resources or the cther econometric problems discussed above. The expansion of the commercial banks Into rural areas had a large effect on fertilizer consumption and on flxed private investment. It also affects output, but with an elasticity of only 0.02 . In order to see how much the bank expansion has contributed we tabulate in table 7 the estimated impact of all independent variable, on the dependent varlables in the deciade of the 1970s. These estimates are the percentage change in the dependent variable caused by the changes in the independent variable, estimated as the product of the change in the Independent variable times the regression coefficlent which is divided by the average value of the dependent voriable. Here we can see the contributions of different factors to growth of dependent variables over the decade, 1971-1981. Obviously the effects of a particular varlable will be small if it did not change much over the decade, irrespective of Its potential impact as measured by the regression coefEicient.

The rapid Bank expansion Increased fertilizer demand by about 23 percent, investment levels in tractors by 13 percent, Investment in pumps by 41 percent, milk animals by 46 percent, and in draft animals by about 38 percent. They also increased the aggregate crop output by nearly 3 
percent. This contribution to output is less than that of any other Infrastructure varfable except canal irrigation and rural electrification. Given the large contribution of the banks to investment and fertilizer use, thelr Impact on output appears to be falrly small. It may arlse because, while spurring specific Investments on account of their lending activity, the banks also may reduce 11quidity in rural areas by their transfer of rural deposits to urban areas. This issue will be investigated in a future paper.

TABLE 7. Contrikiutions of Olfferant Factors to Orowth of Depandent Variebles 1971-1981

\begin{tabular}{|c|c|c|c|c|c|c|}
\hline Variable & Output & Fortillizer & Pump & Tractor & $\begin{array}{l}\text { Dreft } \\
\text { Animel }\end{array}$ & $\begin{array}{c}\text { Milk } \\
\text { Animal }\end{array}$ \\
\hline 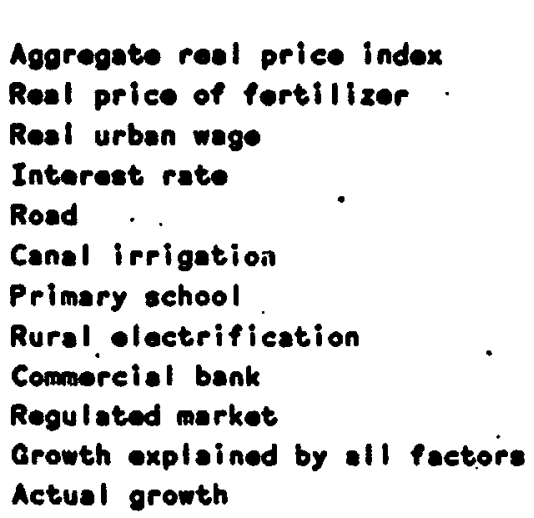 & 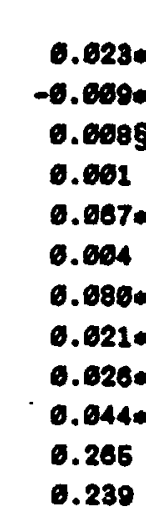 & 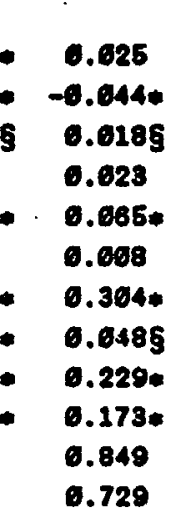 & $\begin{array}{r}-6.028 \\
-0.026 \\
-0.117 \\
-0.018 \\
0.040 \\
-0.068 \\
-6.171 \\
-0.281 \\
-0.468 \\
-0.028 \\
0.341 \\
-0.081\end{array}$ & $\begin{array}{c}-0.068 \\
-0.621 \\
6.254 * \\
0.018 \\
0.161 \\
0.0585 \\
0.067 \\
-6.621 \\
0.131 * \\
0.676 \\
0.694 \\
1.327\end{array}$ & 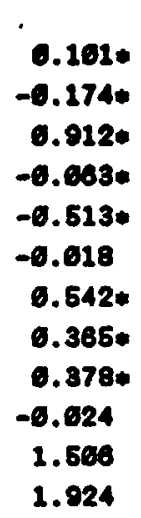 & $\begin{array}{r}0.084 \\
-0.692 * \\
0.658 * \\
-0.012 \\
-0.356 \\
-0.607 \\
0.685 \\
0.271 * \\
0.610 \\
0.678 \\
1.171 \\
1.654\end{array}$ \\
\hline
\end{tabular}

Notg: Asterisk rofors to eignificance iovel of 10 porcent or bottor on a two-tail tast. 5 rofers to significance level of 10 porcent on a ono-tail test.

In addition to estimating the Impact of the banks we have also shown that commercial banks prefer to locate. in well-watered areas where agricultural risks are relatively low and avoid areas characterized by high risks of droughts and floods. Moreover, bank expansion is greatly facilitated by government investments in roads-and regulated markets which 
enhance the liquility position of farmers and reduce transaction costs of both bank and farmers.

Our estimates of interest elasticity of investment while econometrically a bit less secure than the effect of bank expansion, suggest that changes in real interest clearly reduce some of the long-term private investments. On the other hand, we are unable to show an Impact of interest rates on either fertilizer demand or aggregate output, i.e. the impact of higher interest rates on reducing investment in long-term assets is not sufficlently large to have a perceptible impact on output. And for short-term credit used to buy fertilizer it appears that availability of cred1t (as measured by the bank network) is clearly more Important than the Interest rate.

In the reduced form cross-sectional regressions reglons with high Irrigation potential have larger population density, better infrastructure, a more developed banking system, higher private investment rates and higher aggregate crop output. They are also favored in the allocation of new infrastructure and are preferred by banks. They are also able to benefit more from new technology in terms of fertilizer demand, investments and output. On the other hand, the analysis of the government's own additional investment in irrigation between 1961 and 1981 suggest positive, but barely statistically significant, Impact of these irrigation investments on Bank expansion, tractor Investment and crop output. As table 7 shows the estimates imply a near zero contribution of canal Irrigation to aggregate crop output over the 1970s. In order to understand this puzzle it is important to recall that the measure of irrigation potential must include both the already developed as well as the yet to be 
developed potential. There is therefore collinearity between past investment in canal irrigation and potential and the reduced form effects. of Irrigation potential include the effects of the past investments. The fixed effects analysis over time, however, looks only at the impact of the additional government investment over the perfod. Therefore finding a low Impact of recent government investments is not inconsistent with high impact of past investment. This would be especially the case if the rate of return to new canal irrigation had been declining over time as the best sites for 1rrigation became progressively exhausted. Moreover the estimates do not measure the impact of the very important private investment in irrigation. 14 The findings therefore do not imply that private investment In irrigation had a low return, an issue which cannot be analyzed with the technlques utilized. Canal 1rrigation investment in the $1960 \mathrm{~s}$ and $1970 \mathrm{~s}$ was Insigniflcant compared to private investment. Over the 21 years analyzed, area 1rrigated by the government (canal) increased from 58 ha to 75 ha per 1000 ha of geographic area. Area irrigated by wells, 1.e. privately increased much-more rapidly from 54 ha to 114 ha per 1000 ha of geographic area, 1.e. private additions to irrigation exceeded government additions by a factor of nearly 4 to 1 .

Improved road investment has been shown to enhance agricultural output with an elasticlty of about 0.20 . In the 85 sample district roads have on average increased by 40 percent between 1971 and 1981 . Roads would thus have contributed directly 7 percent each to the growth of agricultural

14/ These results are not altered if the canal irrigation variable is replaced by the public irrigation, i.e. including the area under tanks which has been declining. 
output and fertilizer use over this period. We have seen above that they have also contributed to bank expansion. On the other hand, for glven bank density and other infrastructure, the direct effect of roads on private investment is mixed, suggesting that the major effect of roads is not via the1r impact on private agricultural investment but rather on marketing opportunities and reduced transaction costs of all sorts.

Regulated markets have an elasticity with respect to output of 0.08. They have expanded rapidly after 1969 and the growth (87 percent) during this period would have contributed nearly 4 percent to agifcultural output and 17 percent to the demand of fertillzers. As in the case of roads, the markets also have little effect on the private investments, 1.e. thelr effect works directly on output supply decistons.

In contrast electifification has a clear impact on investment in fixed capital, especially on pumps where it has contributed an increase of 28 percent to investment levels. Via these investments and also via fertilizer demand (about 5 percent increase) electrification has increased output over the decade by about 2 percent.

Finally primary education has added 8 percent to crop output over the decade, a very large effect Indeed. This has come about primarily via a nearly 30 percent increment to fertilizer demand.

In terms of prices the study confirms that short run aggregate crop supply elasticities are inelastic even once simultaneity problems which have plagued this literature are overcome. In addition it shows that output prices, fert1lizer prices and urban wages can have substantial 
impacts on private fixed capital investments even in the long run, as the lagged prices in these equations refer to prices ruling in the previous intercensal period, 1.e. 5 years earller on average. The results suggest that wages Increases tend to lead to increased private investment while fertilizer price increases tend to reduce investments. Thus for wages substitution effects dominate the profitabllity effects while for fertilizers the opposite is the case.

The agricultural development literature has been dominated by schools which tended to emphasize the importance, or lack thereof, of specific determinants of agricultural growth. Price fundamentalists have been at odds with 1rrigation determinists. The 1970 s and early 1980 s have been dominated by advocates of cheap sources of growth from agricultural research and education. In World Bank projects road Infrastructure and. market development have taken a backseat relative to the forced expansion of cheap agricultural credit. Advocates of such agricultural credit have been attacked by scholars emphasizing the virtues of savings and marketdetermined interest rates. As the evidence in this paper suggests, reality is far too complex to be put into such black and white terms. Prices really do matter but so do infrastructure, markets, and banks. 
References

Bapna, S.L., H.P. Binswanger and J.B. Quizon, 1984, "Systems of Output Supply and Factor Demand Equations for Semi-Arid Tropical India.", Indian Journal of Agricultural Economics, 39, 179-202.

Barnes, D.F., and H.P. Binswanger, 1986, "Impact of Rural Electrification and Infrastructure on Agricultural Changes, 1966-1980," Econom-c: and Political Weekly, 21, 26-34.

Binswanger, H.P., 1974, "The Measurement of Technical Change Biases with Many Factors of Production", American Economic Review, 64, 964-976.

Blnswanger, H.P., and M.R. Rosenzweig, 1986, "Behavioral and Mater1al Determinants of Production Relations in Agriculture," Journal of Development Studies, 21, 503-539.

Binswanger, H.P., M. Yang, A. Bowers and Y. Mundlak, 1987, "On the Determinants of Cross-Country Aggregate Agricultural Supply," Journal of Econometrics, 36, 111-131.

Boyce, J.K., and R.E. Evenson, 1975, National and International Agricultural Research and Extension Programs, New York: Agricultural Development Council. .

Evenson, R.E., and Y. Kislev, 1975, Agricultural Research and Productivizy, New Haven: Yale University Press.

Lau, L.J., and P.A. Yotopoulos, 1987, "The Meta-Production Function Approach to Technological Change in World Agricuiture," Journal of Development Economics, (forthcoming).

- Mundiak, Y., 1985, The Aggregate Agricultural Supply, Working Paper No. 8511 (Center for Agricultural Economic Research, Rehovat). 
Title

WPS144 Product Differentiation and the

Treatment of Foreign Trade in

CEE Models of Small Economies

WPS145 Revenue Raising Taxes: General

Equilibrium Evaluation of Alternative

Taxation in U.S. Petroleum Industries

WPS146 Exchange Rate-Based Disinflation, Wage Rigidity, and Capital Inflows:

Tradeoffs for Chile 1977-81

WPS147 The Private Sector's Response to

Financial Liberalization in Turkey:

1980-82

WPS148 Impact of the International Coffee Agreement's Export Quota System on the World Coffee Market

Foreign Economic Tles of the USSR

WPS150 Improving the Currency Composition of External Debt: Applications in Indonesia and Turkey

WPS151 U.S. Trade Policy Towards

Developing Countries

WPS152 Subsidies and Countervailing Measures:

Economic Considerations
Timothy condon

vittorlo corbo

Jaime de Melo

Takamasa Aki yama

Panayotis N. Varangis

Bela Balassa

Ken Kroner

Stijn Claessens

Bela Balassa

January 1989

N. Campbell

33769

Date

Contact

February 1989

K. Cabana 61539

February 1989

K. Cabana 61539

W. Pitayatonaka 60353

February 1989

D. Gustafson 33714

N. Campbel I

33769

January 1989

L. Chavarrla 33730

Bela Balassa

January 1989

N. Campbell

33769 
$\underline{T i+10}$

WPS153 An Analysis of Debt Reduction Schemes Initiated by Debtor Countries WPS154 Forecosting, Uncertainty and Public
Project Appraisal

WPS155 Meosuring Adult Mortallty in Developing Countries: A Review and Assessment of Methods

WPS156 Credit Cooperatives in Israell Agriculture

WPS157 A Policy Model for Tunisia with Real and Financial Flows

Marthe de Melo Marc Leduc Setoreh Razmara

Alice Gatenson

Kay McKeough

Mary M. Shirley

Timothy Besley Andrew Powell
Date

Contact

March 1989

L. Chavaria 33730

February 1989

A. Kitson-Walters 33712

March 1989

C. Spooner 37570

January 1989

A. Bhalla 60359

February 1989

W. Wright 33744

March 1989

M. Fernandez 33637

March 1989

R. Molcolm 61708

March 1989

J. Raulin 33715
Miguel A. Kiguel

WPS163 The Impact of Infrastructure and Financial Institutions on Agricultural Output and Investment in India

WPS162 Ups and Downs in Inflation: Argentina since the Austral Plan

Hons $P$. Binswanger Shah idur R. Khandker Mark R. Rosenzweig
March 1989

J. Arevalo 30745 